\title{
VEGETÁRIÁNUS ANYA, VEGETÁRIÁNUS GYERMEK
}

\section{VEGETARIAN MOTHER, VEGETARIAN CHILD}

\author{
Schmidt Judit \\ dietetikus, Magyar Dietetikusok Országos Szövetsége
}

\begin{abstract}
ÖSSZEFOGLALÁS
A vegetáriánus, vegán étrend egyre népszerübb étrendi irányzat, ami valójában egy külön életmódot is jelent. Számos előnye mellett azonban rövid és hosszú távú táplálkozási kockázatokat is magában hordoz, amelyek különösen a várandósság alatti táplálkozás és a csecsemők, kisdedek, gyermekek étrendje szempontjából érdemelnek külön említést. A várandósgondozás során különösen fontos, hogy a leendő édesanya kellő mennyiségű, érthető, hiteles és megbízható információt kapjon a várandósság alatti étrend és a szülést követően a hozzátáplálás, valamint a gyermektáplálás megtervezéséhez. Amennyiben az édesanya a növényi alapú étrend mellett teszi le a voksát, és gyermekét is ebben a szellemben kívánja táplálni, fokozott és szorosabb szakmai kontroll szükséges a szűkített összetételű étrendből eredő egészségügyi problémák megelőzéséhez. Igen alapos táplálkozás-élettani ismeretek birtokában, szoros orvosi, védőnői, dietetikusi felügyelet mellett ugyan összeállítható egy teljes értékű étrend a várandós nők és a gyermekek részére is, azonban mivel mind a várandósság alatti étrend, mind a hozzátáplálás, csecsemőtáplálás számos kihívással járhat az édesanya és a család számára, továbbra is a teljes értékű, vegyes étrend a támogatandó, követendő a hosszú távú egészségmegőrzés érdekében. Kivételként a lakto-ovo, valamint a szemivegetáriánus étrend emelhető ki, mivel ezek esetében minimalizálható a leginkább a táplálkozási kockázat.
\end{abstract}

\section{ABSTRACT}

Vegetarian, vegan diet is an increasingly popular dietary trend, which in fact means a specific lifestyle. Apart from its several benefits, it also takes short and long-term nutritional risks that are particularly worth to mention regarding nutrition during pregnancy and infants', toddlers', and children's diets. When it comes to pre-nursing, it is especially important for the pregnant woman to provide sufficient, understandable, credible and reliable information about the diet of pregnancy and after childbirth to plan for infant and child nutrition. If the mother wants to feed the infant and her child in the spirit of the plant-based diet, there is a need for increased and tighter professional control to prevent health problems caused from a restricted diet. With a thorough dietary knowledge, under close medical, and dietary supervision, a complete diet can be set up for a pregnant woman and her infant, child, but as both diets can have many challenges for the mother and the family still there is a need to support and follow a complete and mixed diet for long-term health care and prevention. As an exception, the lacto ovo and the semi-vegetarian diet can be mentioned, as they can minimize the dietary risk. 
Kulcsszavak: vegetáriánus étrend, vegán étrend, várandósság, diéta, csecsemőtáplálás, gyermektáplálás

Keywords: vegetarian diet, vegan diet, pregnancy, diet, infant nutrition, child nutrition

\section{A VEGETÁRIÁNUS, VEGÁN ÉTREND JELLEMZŐI}

A vegetáriánus étrendről általánosságban elmondható, hogy mellőzi az állati eredetủ táplálékok - a húsok, húskészítmények, belsőségek mellett a tej, tejtermékek, tojás, halak, szalonna, sertés- és egyéb zsírok - fogyasztását. Ez az étrendi irányzat nem egységes, több fajtája ismert, ezek összetételében az étrend követése széles körü motivációjának (többek között a vallási, filozófiai, etikai, kulturális, ökológiai, neveltetésbeli okok) megfelelően nagy egyéni eltérések is lehetnek. Legszigorúbb változata, a vegán étrend minden állati eredetủ tápláléktól mentes, így még a méztől is. A nyers vegán étrend követői a nyersanyagok hőkezelésének semmilyen módját nem fogadják el, jelentősen beszükítve így az étrendi palettát.

A vegetáriánus étrend főbb válfajai közé tartozik a laktovegetáriánus (tejet és tejterméket fogyaszt), ovovegetáriánus (tojást fogyaszt), lakto-ovo vegetáriánus (tejet, tejterméket és tojást fogyaszt), szemivegetáriánus (csak a vöröshúsokat mellőzi), peszketariánus (halakat eszik), fruitariánus (csak gyümölcsöt fogyaszt) és a makrobiotikus étrend (jellemzően gabonaalapú).

A vegetáriánus és vegán étrend követői egyfajta életmódként is megélik az étrendi választásukat. Jellemzően fokozottan figyelnek az egészségükre, kerülik a dohányzást, nem isznak alkoholt, vagy kerülik a mértéktelen alkoholfogyasztást, rendszeresen sportolnak (gyakran jógáznak), fokozott figyelmet fordítanak a környezetvédelemre és a meditációra, relaxációra is. A legtöbb táplálkozási vizsgálat során ezek a tényezök is fontos szempontot jelentenek, mivel nehezebb elkülöníteni a csak táplálkozás eredetủ eltéréseket és az életmód egyéb elemeiből eredő hatásokat.

A növényi alapú étrend előnyei közé sorolható többek között, hogy az állati eredetü táplálékok jelentősebb fehérje-, zsír-, telítettzsírsav-, koleszterintartalma miatt már önmagában ezek fogyasztásának mérséklése is csökkentheti egyes szív- és érrendszeri betegség (iszkémiás szívbetegség, magas vérnyomás...), egyes daganatos betegségek, a 2-es típusú cukorbetegség, valamint az elhízás kockázatát is. Ugyanakkor a szükebb nyersanyagválaszték, így bizonyos tápanyagok hiányos felvétele miatt a növényi étrend számos kockázatot is magában foglal, amely különösen a várandósság, a szoptatás és a hozzátáplálás során járhat akár hosszabb távú egészségügyi következményekkel. A továbbiakban ezek ismertetésére kerül sor. 


\section{A VÁRANDÓSSÁG ALATTI VEGETÁRIÁNUS, VEGÁN ÉTREND HATÁSAI A MAGZATRA}

A várandósság során megnő az anya energia- és tápanyagszükséglete is, hogy az ennek megfelelően kibővített, átalakított étrendje ezáltal is támogassa a magzat fejlődését, növekedését, valamint az anyai szervezetben bekövetkező változásokat. A helytelenül összeállított/túl szigorú vegetáriánus étrend azonban számos, az állati eredetủ táplálékokban elégséges mennyiségben fellelhető tápanyagból hiányos lehet, vagy nem jól felszívódó formában tartalmazza némelyiket, ezáltal a vegetáriánus/vegán étrend során a magzat növekedése, fejlődése szempontjából a már említett veszélyekkel is járhat.

A várandósság alatti vegán és a makrobiotikus táplálkozás különösen a várt testtömeg-növekedés elmaradása, valamint a magzat nem megfelelö testi fejlödése, a vérszegénység, a csontritkulás, egyes felszívódási zavarok, a fokozott koraszülési kockázat, a kis születési súly révén okozhat problémát, amely állapotok föleg a fehérje, kalcium, vas, cink, $\mathrm{B}_{6}$-, $\mathrm{B}_{12}$ - és a D-vitamin hiányával függnek össze. A továbbiakban ezen kiemelt tápanyagokkal és a hiányukból eredő zavarokkal foglalkozunk.

Fehérjék

A különböző fehérjeforrások aminosav-összetétele és a fehérjekomplettálás lehetőségei

\begin{tabular}{|c|c|c|c|}
\hline $\begin{array}{c}\text { Élelmiszer- } \\
\text { csoport }\end{array}$ & $\begin{array}{c}\text { Limitáló esszenciális } \\
\text { aminosav }\end{array}$ & $\begin{array}{c}\text { Bőséges esszenciális } \\
\text { aminosav }\end{array}$ & Fehérjekomplettálás \\
\hline tojás & nincs & $\begin{array}{l}\text { cisztin, lizin, } \\
\text { metionin, triptofán }\end{array}$ & komplett fehérje \\
\hline gabonafélék & lizin, izoleucin & $\begin{array}{l}\text { cisztin, metionin, } \\
\text { treonin, triptofán (a } \\
\text { kukorica és a rizsliszt } \\
\text { triptofánban szegény) }\end{array}$ & $\begin{array}{l}\text { gabonafélék + hüvelyesek } \\
\text { gabonafélék + tej és olajos } \\
\text { magvak }\end{array}$ \\
\hline hüvelyesek & $\begin{array}{l}\text { metionin, cisztin, } \\
\text { triptofán (kivéve } \\
\text { szójabab, ami } \\
\text { triptofánban gazdag) }\end{array}$ & lizin, metionin & $\begin{array}{l}\text { hüvelyesek + gabonafélék } \\
\text { hüvelyesek + olajos magvak }\end{array}$ \\
\hline $\begin{array}{l}\text { tej, } \\
\text { tejtermékek }\end{array}$ & nincs & $\begin{array}{l}\text { lizin, izoleucin, } \\
\text { metionin }\end{array}$ & komplett fehérje \\
\hline $\begin{array}{l}\text { diófélék, } \\
\text { olajos } \\
\text { magvak }\end{array}$ & $\begin{array}{l}\text { lizin, izoleucin } \\
\text { (kivéve kesudió, } \\
\text { tökmag) }\end{array}$ & $\begin{array}{l}\text { cisztin, metionin, } \\
\text { triptofán (kivéve } \\
\text { földimogyoró, ami } \\
\text { metioninban és } \\
\text { triptofánban szegény) }\end{array}$ & olajos magvak + hüvelyesek \\
\hline zöldségek & $\begin{array}{l}\text { cisztin, metionin, } \\
\text { izoleucin (kivéve } \\
\text { spenót) }\end{array}$ & lizin, triptofán & $\begin{array}{l}\text { zöldségek + diófélék + tojás } \\
\text { zöldségek + gabonafélék + tej } \\
\text { hüvelyesek + tej, tejtermék }\end{array}$ \\
\hline
\end{tabular}


A növényekben nem található meg az összes esszenciális (létfontosságú, a táplálék útján fedezendő) aminosav, vagy nem megfelelö arányban, mennyiségben. Emiatt a növényi eredetủ fehérjéket nem teljes értékűnek (inkomplettnek) tekintjük. Azonban a növényi eredetủ nyersanyagokból származó fehérjéket az állati eredetűekkel együtt fogyasztva jobban hasznosulnak a bennük található esszenciális aminosavak, illetve a különbözö aminosav-szerkezetü növények együtt kiegészíthetik/komplettálhatják egymást. Ennek köszönhetően a fehérje-, aminosavhiány nem feltétlenül jelent akkora problémát a vegetáriánus/vegán étrendben, amennyiben a komplettálásra a megfelelő dietetikai ismeretek birtokában kellöképpen odafigyel az édesanya (és erre a várandósság alatt a megfelelő végzettségű egészségügyi szakember, ideális esetben a dietetikus, felhívja a figyelmet).

Vas

A várandósság során megnövekedett vasszükséglet fedezése a zöldségekkel, gyümölcsökkel, gabonákkal, magvakkal, hüvelyesekkel teljes mértékben nem lehetséges, mivel a növényi eredetü (nem hem) vas hasznosulása kisebb az állati eredetủ élelmiszerekben található (hem) vasénál. A vashiány megelőzését segíti azonban az a tény, hogy a vegetáriánus étrend jelentős mennyiségü, a vas biológiai hasznosulását segítő C-vitamint tartalmaz, ezzel is csökkentve az akut és krónikus vashiány okozta lehetséges szövődményeket. Ettől függetlenül a vegetáriánus/vegán étrendet követő várandósoknak a vashiányos anémia megelőzése érdekében szükséges lehet az orvosi javaslatra és kontroll mellett folytatott vaspótlás, amennyiben étrendi úton nem lehetséges a vasszükséglet fedezése, és a vérvételi eredmények is indokolják a szükségességét.

\section{Kalcium}

A tej, illetve a tejtermékek kihagyásával nehezen fedezhető teljes egészében a csontok, fogak és az izom-idegrendszer számára nélkülözhetetlen kalcium szükséglete, amely a növényi alapú étrendek jelentős rost- és fitáttartalmából eredő felszívódási nehézségek miatt még nagyobb kihívást jelent. Azoknak a várandós nőknek, akiknek az étrendje nem tartalmaz elegendő mennyiségü kalciumot, kalciummal dúsított élelmiszereket (például: kalciummal dúsított növényi italokat, tejhelyettesítőket) javasolt fogyasztania, vagy kalciumtartalmú étrend-kiegészítőt ajánlott szednie orvosi felügyelet mellett.

$$
\mathrm{B}_{6} \text {-vitamin }
$$

A magzat agymüködéséhez és idegrendszerének kifejlődéséhez szükséges, csökkentheti az anyai hányinger, hányás előfordulását. Hiánya felelőssé tehető a terhességi depresszióért, bár, mivel az állati eredetủ táplálékok (máj, húsok, halak) 
mellett a növényi eredetủ élelmiszerek is tartalmazzák (például a káposzta, a szójatermékek, a barnarizs), ez a veszély a vegetáriánus/vegán étrend mellett nem fenyegetö.

$$
\mathrm{B}_{12} \text {-vitamin }
$$

A $B_{12}$-vitamin kizárólag állati eredetủ termékekben található meg, a várandósság alatti hiánya visszafordíthatatlan idegrendszeri károsodást okozhat a magzatnál, emiatt a növényi alapú étrend esetében ez a vitamin kiemelt jelentőséget kap. Felnőtteknél öt-tízévnyi hiányos felvétel után jelentkezik csak a hiánya, mivel a májban viszonylag nagy mennyiségben raktározódik, a szervezet képes újrahasznosítani a már elfogyasztott mennyiséget. Az alternatív táplálkozási irányzatok által terjesztett nézetekkel ellentétben a különböző algák (nori, spirulina), tengeri növények, fermentált szójakészítmények (szójaszósz, miszo, tempeh), élesztő $\mathrm{B}_{12}$-vitamin-tartalma nem fedezi a szükségleteket.

\section{Cink}

A vegetáriánus étrend során a várandós nők cinkszükséglete nagyobb lehet, mivel a növényi alapú étrendböl a cink felszívódása rosszabb. Ez azonban fokozható a növényi eredetű forrásokból: a csíráztatott gabona-/babfélékből, a fermentált szójakészítményekből (tempeh, miszo), az olajos magvakból, az élesztővel sütött kenyerekből, a hüvelyesek beáztatásával, főzésével, a cinktartalmú ételek savas ételekkel (citromlé, paradicsomszósz) történő kombinálásával. Külső pótlása ezáltal nem feltétlenül válik szükségessé.

\section{D-vitamin}

Még a legjobban összeállított vegyes étrend sem tudja teljes egészében fedezni a napi szükségletet (a napi 10-15 perces, nem a déli órákban történő napozás hatása ezt azonban kiegészíti). Ráadásul a vitamin a kizárólag növényi alapú étrendben még kisebb mennyiségben van jelen. A várandós anya D-vitamin-hiánya zavart okozhat az utód neurokognitív fejlődésében. A várandósság alatti D-vitamin-pótlás ellenben csökkenti a beszédzavar kockázatát. A D-vitamin pótlását - csepp, tabletta vagy kapszula formájában - a többi étrend-kiegészítőhöz hasonlóan orvossal célszerủ egyeztetni, a túladagolás elkerülése érdekében.

\section{Ómega-3 zsírsavak}

A hosszú szénláncú, többszörösen telítetlen zsírsavak, így a dokozahexénsav (DHA) és az arachidonsav fontos szerepet játszanak az idegrendszer igen intenzív perinatális fejlődésében. A vegán, vegetáriánus étrendről elmondható, hogy 
DHA-hiányos, mivel ez a zsírsav elsősorban a halakban, a tengeri állatok húsában és a tojásban található meg. A növényi eredetủ ómega-3 forrásai közé többek között a dióolaj, lenmagolaj, szőlőmagolaj, repceolaj tartozik, így a hiányállapot megelőzése érdekében ezeket az olajokat célszerü gyakrabban az anyai étrendben szerepeltetni. Azok a gyermekek, akiknek édesanyja a várandósság és a szoptatás során ómega-3 zsírsav-kiegészítést kapott étrend-kiegészítő formájában, szignifikánsan jobb teljesítményt mutattak a mentális feldolgozás altesztben (Helland et al., 2003). A 13. héttől az ómega-3 zsírsav (DHA) adása az anya lelki egészsége és a baba kognitív és pszichomotoros fejlődése céljából is indokolt, különösen amennyiben az étrenddel történő felvétel korlátozott, hiányos.

\section{VEGETÁRIÁNUS-VEGÁN ÉTREND CSECSEMŐ-, KISDED-ÉS GYERMEKKORBAN}

A vegán étrendet követő szülők csecsemője esetén vegán hozzátáplálásról beszélünk, ami manapság már nem ritka jelenség, tekintve, hogy egyre terjednek az alternatív étrendek, bár legtöbbször sajnos szakmailag megalapozatlan források és egészségügyi végzettséggel nem rendelkező tanácsadók révén.

A szigorú vegetáriánus (vegán) diétát követő anyák anyateje elégtelen menynyiségben tartalmazza nemcsak a $\mathrm{B}_{2}$ - és $\mathrm{B}_{12}$-vitamint, de a vas, kalcium és cink koncentrációja is nagyon alacsony. Ilyen esetekben az anyatej mennyiségi és minőségi fehérje-összetétele sem megfelelö, ezért a csecsemőnél egyes létfontosságú aminosavakból hiány alakulhat ki.

Dietetikai és egészségügyi szempontból a jelenlegi hazai álláspont alapján ez az igen szigorú étrend nem felel meg sem a csecsemők hozzátáplálásának, sem a kisdedek és a gyermekek szükségleteinek, mivel az intenzív testi-szellemi fejlódéshez megfelelő mennyiségben az összes makro- es mikrotápanyag szükséges.

A Deutsche Gesellschaft für Ernährung e. V. (DGE) állásfoglalása ezzel egyezik, így a táplálékhiány kockázatának minimalizálása érdekében, különösen az élet első évében, a DGE olyan étrendet ajánl, amely magában foglalja az élelmiszerkörben felsorolt összes élelmiszercsoportot.

Az alábbiakban a kiemelten a csecsemőket, kisdedeket, gyermekeket érintő és eddig nem részletezett tápanyaghiányok és az azokból eredő kockázatok csökkentésének ismertetése következik.

\section{Fehérje}

Kizárólag növényi eredetű étrend esetén a fehérjefelvételt csaknem 5\%-kal szükséges növelni, vagyis csecsemők esetén az energia nem 30, hanem 35\%-át kell ebböl fedezni kétéves korig, 20\% helyett 30\%-ot két- és hatéves kor között, ennél idősebb korban pedig $15 \%$ helyett $20 \%$-ot. A hozzátáplálás során bevezetett 
vegán ételek nagy tömegủek és jelentős rosttartalmúak, s mivel a csecsemő egyszerre csak kis mennyiségeket fogyaszt, ezért növelni kell az étkezések energiatartalmát is (például a szójatermékek, mogyorófélék, mogyoróvaj és a hüvelyesek gabonával történő kombinálásával).

$$
B_{12} \text {-vitamin }
$$

Az anyai vegán étrend és a kizárólagos anyatejes táplálás mellett leggyakrabban $\mathrm{B}_{12}$-vitamin-hiány alakul ki. A csecsemöknél a hiányállapot tünetei között a súlyfejlődésben való elmaradás, vérszegénység, ismétlődő hányások, bágyadtság, megnőtt alvásigény, nyelési nehezítettség, székrekedés, remegés szerepelhet. Súlyosabb esetben figyelemzavar, idegrendszeri károsodások, retardáció is fellépnek. Emiatt a várandósság és a szoptatás alatt a vegán étrend nemcsak a $B_{12}$-vitamin, hanem az esszenciális zsírsavak elégtelen felvétele miatt is ellenjavallt. Amennyiben az anya nem mond le a vegán diétáról, szükséges a $B_{12}$-vitamin szintjének ellenőrzése és az egyéb hiányállapotok szürése (fizikális vizsgálat, idegrendszeri vizsgálat, vérkép). Súlyos fokú hiány esetén a pótlás megfelelő módon csak az izomba adott $\mathrm{B}_{12}$-vitamin-injekció formájában lehetséges. Ezen esetekben szükségessé válhat az anyatejes táplálás helyett a mesterséges táplálásra (tápszerre) való áttérés is. Igen súlyos, leromlott állapot esetén infúziós kezelés, súlyos vérszegénység esetén transzfúzió is szükséges lehet. Ideális esetben idáig nem fajul a helyzet, és az étrend megfelelő kiegészítésével (célzottan adagolt étrend-kiegészítőkkel) vagy az állati eredetủ táplálékok elfogadtatásával megoldható a helyzet, amennyiben az édesanyát sikerül meggyőzni ennek szükségességéről.

Vas

A vashiány csecsemő- és kisgyermekkorban a vérszegénység mellett pszichomotoros (észlelési, tér-tájékozódási, mozgásszervezési, koordinációs, egyensúlyozási készségek és képességek) fejlődési rendellenességet és viselkedési zavart is okozhat. A problémát az okozza, hogy az utólagos, későbbi pótlással ezek az eltérések már nem fordíthatók vissza, ezért a vashiány megelőzésére kell törekedni. Vegán étrend esetén ezért a vaskiegészítés mindenképpen javasolt az intenzív növekedés időszakában.

\section{Rost}

Tekintve, hogy a vegetáriánus, vegán étrend jelentős mennyiségủ rostot tartalmaz, a tápanyagok optimálisabb felszívódása érdekében a zöldségek, gyümölcsök meghámozása és a finom őrlésủ gabonafélék előnyben részesítése javasolható a kisdedek, gyermekek esetében. 
Jód

A kizárólag vegán anya anyatejével táplált csecsemőknél jódhiánnyal és pajzsmirigy-alulmüködéssel számolhatunk. A jódhiány megelözéséhez a hozzátápláláskor a jóddal dúsított gabonapépekkel is hozzájárulhatunk a jódfelvétel optimalizálásához.

\section{D-vitamin}

A szűk élelmiszer-választék és a D-vitamin-pótlás esetleges elutasítása angolkórhoz (rachitis), illetve hipokalcémiához vezethet a vegán módon táplált csecsemők és kisgyermekek körében. Az első életévben ennek megelőzésére a D-vitamin külső pótlása erősen ajánlott.

\section{SZAKMAI ÁLLÁSPONTOK A VÁRANDÓS ANYÁK ÉS GYERMEKEIK VEGETÁRIÁNUS, VEGÁN ÉTRENDJÉVEL KAPCSOLATBAN}

A viszonylag kis számú, a várandósság alatti vegán-vegetáriánus étrendre vonatkozó bizonyítékok többnyire heterogének. A randomizált vizsgálatok hiánya megakadályozza, hogy megkülönböztessük az étrend hatásait az egyéb zavaró tényezőktől (például a bevezetőben már említett életmódbeli szokásoktól). Elsősorban a külföldi táplálkozástudományi irányelvek alapján a megfelelöen összeállított vegán vegetáriánus étrendet a várandósság alatt biztonságosnak lehet tekinteni, feltéve, hogy az anya kiemelt figyelmet fordít a várandósság, a szoptatás alatt és a gyermek étrendje esetében is a vitaminok és nyomelemek szükségletének célzott fedezésére.

A European Society for Paediatric Gastroenterology, Hepatology, and Nutrition (ESPGHAN) javaslata szerint a vegán étrendet kizárólag megfelelő orvosi és dietetikai felügyelet mellett szabad alkalmazni, s fel kell hívni a szülők figyelmét a súlyos következményekre, amennyiben nem követik az étrend adekvát kiegészítésére vonatkozó szakmai javaslatokat.

Az Academy of Nutrition and Dietetics (Táplálkozástudományi és Dietetika Akadémia) álláspontja szerint a megfelelően megtervezett vegetáriánus és a vegán étrend is egészséges, táplálkozási szempontból megfelelö, környezetvédelmi és egészségügyi előnyökkel járhat bizonyos betegségek megelőzését és kezelését tekintve. Ezeket az étrendeket megfelelönek tartja az életciklus minden szakaszában, beleértve a várandós, szoptató nőket, a csecsemőket és a gyermekeket, a serdülöket, az idősebb felnőtteket és a sportolókat is.

Ugyanakkor hazánkban ezt a kijelentést csak erős kérdőjelekkel és szük keretek, feltételek között mondhatjuk érvényesnek, a hazai táplálkozási vizsgálatok eredményei, az ország lakosságának egyenlőtlen szociális, gazdasági lehetőségeit, viszonyait, táplálkozástani ismereteinek mértékét tekintve is. 
Igen alapos dietetikai ismeretek birtokában, szoros orvosi és védőnői felügyelet mellett ugyan összeállítható egy teljes értékủ étrend a vegetáriánus és vegán csecsemők és kisgyermekek részére is, azonban figyelembe kell venni azt a tényt is, hogy a várandósság és a hozzátáplálás alatti étrend a vegyes étrend esetén is számos kihívással jár az édesanya és a család számára, amit a szúkített étrend csak tovább nehezíthet. A növényi alapú étrend ugyanis a hagyományostól eltérö alapanyagok beszerzését, újfajta receptek, ételkombinációk megtervezését, elkészítését teszi szükségessé, valamint kiterjedt és alapos táplálkozás-élettani ismereteket követel meg (többek között a fehérjekomplettálás, az egyes vitaminok, ásványi anyagok forrásait, felszívódását illetően), valamint a szélsőséges étrendi irányzatok (például a nyers vegán étrend) kerülését. Emiatt elmondható, hogy bár számos intézet ellenkezően nyilatkozott, összlakossági szinten a táplálkozási kockázatokat tekintve a vegán és a szigorú vegetáriánus étkezés szakmailag nem biztonságos módja a várandós nők táplálkozásának, illetve a csecsemők, kisdedek, gyermekek táplálásának, tekintve, hogy számos, a magzat méhen belüli és a születést követő egészségi állapotát is érintő kockázatot rejthet magában. A kivételt a gondosan, kellő változatossággal, szakszerủen összeállított lakto-ovo, szemivegetáriánus étrend jelenti, amely már megfelelő alternatíva lehet a várandós nő egészsége és a magzat fejlődése szempontjából is. Ezek összeállításában dietetikussal történő konzultáció is szükségesnek tekinthető a megfelelö ételpárosítások, tápanyagforrások kiválasztása céljából. A lehetséges tápanyaghiányok és az azokból eredö következmények elkerülése érdekében azonban továbbra is a vegyes, kiegyensúlyozott, vagyis állati, növényi táplálékokat egyaránt tartalmazó étrend javasolt.

Amennyiben a kismama vegetáriánus étrendet kíván folytatni, a cél az, hogy a legnagyobb gondosság mellett összeállított étrendjéből a hiányzó tápanyagok erre a célra szolgáló gyógyszerekkel, étrend-kiegészitőkkel való pótlása csak orvosi javaslatra és felügyelettel történjen az esetleges túladagolás és annak következményei megelőzése érdekében. A rendszeres orvosi vizsgálatokon való megjelenés mellett indokolttá válik a dietetikussal történő rendszeres konzultáció is, amelyre a védőnő és/vagy a kezelőorvos is felhívhatja a figyelmet, amennyiben a várandós nem maga jelentkezik dietetikai tanácsadásra.

A helyzetet nehezíti, hogy a hazai gyakorlat szerint a dietetikusok nem részei a várandósgondozásnak, a speciális, szakellátást igénylő eseteket kivéve (például gesztációs diabétesz). Emiatt a várandósok által önkényesen választott alternatív étrend, így például a vegetáriánus, vegán étrend követése esetén a dietetikusok nem vagy csak ritkán, egyéni megkeresés révén (például magánpraxis keretein belül) találkoznak a várandóssal. A rendszeres és szoros szakmai kontroll (amely gyakoribb orvosi szüréseket és vizsgálatokat is jelent) a szükséges mértékü étrend-kiegészítés mellett azonban biztosíthatja a zavartalan várandósságot és szülést, valamint a csecsemő, kisded, gyermek megfelelő testi-szellemi fejlődését. 


\section{IRODALOM}

Aradvári-Szabolcs M. (2012): Csecsemőtáplálás vegán módra. Új Diéta, 2, 24-25.

Domonkos A. - Greiner E. (1999): A vegetáriánus táplálkozás és a terhesség I. Új Diéta, 2, 4. http://www.ujdieta.hu/index3c6c.html?content $=410$

Domonkos A. - Greiner E. (1999): A vegetáriánus táplálkozás és a terhesség II. Új Diéta, 2, 6. http://www.ujdieta.hu/indexfb92.html?content=393

Fewtrell, M. - Bronsky, J. - Campoy C. et al. (2017): Complementary Feeding: A Position Paper by the European Society for Paediatric Gastroenterology, Hepatology, and Nutrition (ESPGHAN). Committee on Nutrition, 64, 1, 119-132. DOI: 10.1097/MPG.0000000000001454

Helland, I. B. - Smith, L. - Saarem, K. et al. (2003): Maternal Supplementation with Very-longchain n-3 Fatty Acids during Pregnancy and Lactation Augments Children's IQ at 4 Years of Age. Pediatrics, 111, 1, e39-44. https://pediatrics.aappublications.org/content/pediatrics/111/1/ e39.full.pdf

Piccoli, G. B. - Clari, R. - Vigotti, F. N. et al. (2015): Vegan-vegetarian Diets in Pregnancy: Danger or Panacea? A Systematic Narrative Review. BJOG, 122, 5, 623-633. DOI: 10.1111/14710528.13280, https://obgyn.onlinelibrary.wiley.com/doi/full/10.1111/1471-0528.13280

Polyák É. - Krassói A. - Bonyárné Müller K. et al. (2012): A vegetáriánus táplálkozás hatása várandósság alatt, Új Diéta, 2, 22-23. http://mdosz.hu/hun/wp-content/uploads/2016/03/ ud2012_2-_vegleges.pdf

Vesanto, M. - Winston, C. - Susan, L. (2016): Position of the Academy of Nutrition and Dietetics: Vegetarian Diets. Physicians Committee for Responsible Medicine, Washington, DC, PlumX Metrics. 116, 12, 1970-1980. DOI: 10.1016/j.jand.2016.09.025, https://www.eatrightpro.org/ / media/eatrightpro $\% 20$ files/practice/position $\% 20$ and $\% 20$ practice $\% 20$ papers/position $\% 20$ papers/vegetarian-diet.ashx

URL: Perikoncepcionális gondozás. A pozitív családtervezés jelentösége a veleszületett rendellenességek megelözésében. http://www.egeszseg.hu/szakmai_oldalak/oldal/szervezeti-egysegek/ gyermekegeszsegugyi-igazgatosag-perikoncepcionalis-gondozas/

URL: Vegane Ernährung: Nährstoffversorgung und Gesundheitsrisiken im Säuglings- und Kindesalter. DGEinfo, 2011, 04. https://www.dge.de/wissenschaft/weitere-publikationen/fachinformationen/vegane-ernaehrung-saeugling-kindesalter/ 